\title{
Preliminary assessment of the Gut weed Ulva intestinalis as food for herbivorous fish
}

\author{
Muhammad Abu Bakar Siddik • Nguyen Thi Ngoc Anh
}

Received: 4 September 2014/Accepted: 29 November 2014/Published online: 12 December 2014

(C) The Author(s) 2014. This article is published with open access at Springerlink.com

\begin{abstract}
A set of feeding trials was carried out to assess the potential use of gut weed (GW) Ulva intestinalis as a direct food to replace commercial feed (CF) in an alternative approach for feeding Spotted scat (Scatophagus argus), Red tilapia (Oreochromis niloticus), and Giant gourami (Osphronemus goramy) juveniles for 60,45 , and 56 days, respectively. Four feeding regimes were assigned to triplicate tanks. The different groups were fed CF every day, GW every day, and one day of CF followed by one (1CF_1GW) or two (1CF_2GW) days of GW, respectively. The results indicated that growth performance of the S. argus fed on single GW was not significantly different from the control group but the performance of $O$. niloticus and $O$. goramy in the alternative feeding treatments were comparable to the control. The feed conversion ratio could be reduced by $26.1-57.8 \%$ in the combined feeding regimes to control will minimize the production cost of fish. Water quality in terms of $\mathrm{NO} 2$ and $\mathrm{NH} 4 / \mathrm{NH} 3$ in the rearing tanks was better in the combined feeding than in the single CF. These results indicated that GW can be used as a food to partially substitute CF for herbivorous fish.
\end{abstract}

Keywords Gut weed $\cdot$ Macroalgae $\cdot$ Water quality $\cdot$ Herbivorous $\cdot$ FCR $\cdot$ Ulva intestinalis

\section{Background}

Gut weed (GW) Ulva intestinalis (Linnaeus) a macroalga distributed in a wide variety of environments from freshwater to seawater including ocean coast, brackish waters, and inland freshwater all over the world (Ergun et al. 2009; Siddik et al. 2014a). It has high nutritional values such as 9-14\% protein, 2.0-3.6\% lipids, and $32-36 \%$ ash on a dry weight basis. In addition, the $n-3$ and $n-6$ fatty acids pose 10.4 and $10.9 / 100 \mathrm{~g}$ of the total fatty acids. It is also rich in essential amino acids, pigments, and minerals (Haroon et al. 2000; AguileraMorales et al. 2005; Shanmugan and Palpandi 2010). It can therefore be used as an ingredient in diets or as direct feed for fish/shrimp and for integrated aquaculture system (FAO 2011). Macroalgae have been reported in several studies as a booster for keeping water quality better in intensive culture of fish (Valente et al. 2006;

M. A. B. Siddik $(\bowtie)$

Sado Marine Biological Station, Faculty of Science, Niigata University, Niigata, Japan

e-mail: siddik@pstu.ac.bd

M. A. B. Siddik

Department of Fisheries Biology and Genetics, Patuakhali Science and Technology University, Patuakhali, Bangladesh

N. T. N. Anh

College of Aquaculture and Fisheries, Can Tho University, Can Tho, Vietnam 
Ergun et al. 2009; Siddik et al. 2014a). Since tropical fish are generally sensitive to poor water quality and a large number of fish is kept in a small tank during the culture period, the water quality should be given prime importance for keeping fish in tranquil. Using GW as food for fish can play a dual role to maintain good condition of water for better production in one hand and on the other hand, its incorporation may reduce feed cost for the fish production (Anh et al. 2012).

The long-term sustainability of aquaculture may be threatened by its present over-dependence on fish meal and fish oil (FAO 2011). Moreover, fish feeding represents over $50 \%$ of operating costs in intensive aquaculture, with protein being the most expensive dietary source (Aguilera-Morales et al. 2005; Ergun et al. 2009). An intensive effort during the last decades has been made in order to evaluate the potential of alternative protein sources in aquaculture (El-Sayed 1999; Rad et al. 2013). Several studies have been conducted to evaluate the replacement of fish meal by plant ingredients in diets of European sea bass and Tilapia (Valente et al. 2006; Pereira et al. 2012; Kaushik et al. 2004). However, research data about the potential use of macroalgae in herbivorous fish diets is scarce (El-Sayed, 1999; Pereira et al. 2012). Therefore, the aim of this study was to assess the effect of commercial feed (CF) replacement with GW as direct feed on water quality, growth, and feeding efficiency of the herbivorous fishes like Spotted scat (Scatophagus argus), Red tilapia (Oreochromis niloticus), and Giant gourami (Osphronemus goramy). This work could encourage farmers using local availability of GW as food source for fish, and it could contribute to reduce feed costs and provide more profits for farmers.

\section{Materials and methods}

\section{Experimental design}

Three separate experiments were performed in the experimental hatchery complex of the College of Aquaculture and Fisheries, Can Tho University, Vietnam in the period from January to September, 2012. The fresh and dried GWs were used as a direct feed to replace CF in alternative regimes for feeding $S$. argus, $O$. niloticus, and $O$. goramy juveniles for 60,45 , and 56 days, respectively.

Four feeding regimes were assigned to triplicate tanks. The different groups were fed CF every day, GW every day $(\mathrm{GW})$, and one day of $\mathrm{CF}$ followed by one (1CF_1GW) or two (1CF_2GW) days of GW, respectively.

\section{Experiential diets}

Fresh GW U. intestinalis was collected from the extensive farm of Bac Lieu province, Vietnam and cleaned with $5 \mathrm{~g} / \mathrm{L}$ saline water to maintain the quality. Dried GW was obtained by air drying a thin layer of biomass until reaching a moisture content of 12-14\%. Both fresh and dried GWs were cut with scissors into small pieces $( \pm 2 \mathrm{~mm}$ ) for feeding the fish. The CF (GROBEST-GB640) used in this study had the crude protein $\geq 30 \%$, lipid $\geq 6 \%$, ash $\geq 14 \%$, fiber $\geq 6 \%$, and moisture $\geq 11 \%$ (information from manufacturer). Proximate composition (\% of dry matter) of GW was analyzed by the standard methods of AOAC (2005), giving a protein content of $12.7 \pm 2.6 \%$, a lipid content of $2.4 \pm 0.2 \%$, an ash content of $32.4 \pm 7.6$, a fiber content of $4.5 \pm 1.1 \%$, and a carbohydrate content of $47.9 \pm 6.7 \%$.

Culture system

The 100-L plastic tanks were filled with $80 \mathrm{~L}$ water with salinity of $5 \mathrm{~g} / \mathrm{L}$ for $S$. argus and with freshwater for $O$. niloticus and $O$. goramy. 30 fish were introduced in each tank, provided with continuous aeration and were fed to satiation twice a day at 8:00 a.m. and 4:00 pm. Uneaten feed was collected after $1.5 \mathrm{~h}$ of feeding. The water exchange rate was approximately $50 \%$ of the tank volume every third day.

Data collection

Water temperature, dissolved oxygen, and $\mathrm{pH}$ were recorded twice a day at 7:00 and 14:00 h. Temperature and $\mathrm{pH}$ were determined using a thermo $\mathrm{pH}$ meter (YSI 60 Model, HANNA instruments, Mauritius). The 
dissolved oxygen (DO) was determined using a DO meter (YSI, Model-58, USA), and the concentrations of $\mathrm{NO} 2$ and NH4/NH3 (TAN) were determined weekly using DREL/2 HACH kits (HACH Co., Loveland, CO, USA). For the estimation of growth performance of fishes, weights were recorded and average growth calculated throughout the experimental period. Samples for this purpose were collected at the beginning and end of the study, along with every 14th or 15th day of the experimental period. Specific growth rate (SGR), feed conversion ratio (FCR), and survival rate were calculated using the following equations:

SGR $(\% /$ day $)=($ Final weight - Initial weight $) /$ culture period $\times 100$.

Survival $(\%)=$ Final number of fish/Initial number of fish $\times 100$.

$\mathrm{FCR}=$ Feed intake (dry weight)/Weight gain (wet weight).

Statistical analysis

Statistical analysis of all measured variables was performed using SPSS for windows, Version 14.0. Variations of dietary treatments were compared by one-way ANOVA. The Tukey HSD post hoc analysis was used to detect differences between means.

\section{Results and discussion}

Water quality parameters

Daily water temperature, dissolved oxygen, and $\mathrm{pH}$ over three experiments fluctuated in the ranges of 26.5-30.2 ${ }^{\circ} \mathrm{C}, 4.90-5.66 \mathrm{mg} / \mathrm{L}$, and 7.1-8.3, respectively. These factors were generally within the suitable range for tropical fish growth (Boyd 2003; Siddik et al. 2014b; Ahsan et al. 2013). However, the mean concentrations of dissolved inorganic nitrogen such as NO2 and TAN ranged from 0.04 to $1.85 \mathrm{mg} / \mathrm{L}$ and $0.02-0.97 \mathrm{mg} / \mathrm{L}$, respectively. These values were highest at the end of the experiment and higher in the control treatment (commercial feed) compared to other treatments (Fig. 1).

The results showed that feeding treatments had significant effects on water quality. The mean concentration of NO2 and TAN tended to increase during the culture period in all groups. The highest concentrations of NO2 $(1.5 \mathrm{mg} / \mathrm{L})$ and TAN $(0.90 \mathrm{mg} / \mathrm{L})$ were observed in the control group, followed by the 1CF_1GW and the 1CF_2GW groups. The lowest values (NO2 of $0.33 \mathrm{mg} / \mathrm{L}$ and TAN of $0.28 \mathrm{mg} / \mathrm{L}$, respectively) were found in the group fed only GW. This indicates that the water quality is much better in the rearing tanks with GW than in the tanks with only CF. Hence, the concentration of N-nutrients in the culture tanks was increased with regard to the amount of pellet feeds used, which could be reduced by water exchange. For aquaculture production, suitable level of $\mathrm{NO} 2$ and TAN for aquatic animals should be less than 0.5 and $0.2-2 \mathrm{mg} / \mathrm{L}$, respectively (Rahman et al. 2008; Zhao et al. 2014). However, in the present study, because of the relatively high rate of water exchange (about $50 \%$ of volume for every 3 days interval), these parameters might not be harmful to the experimental fish.
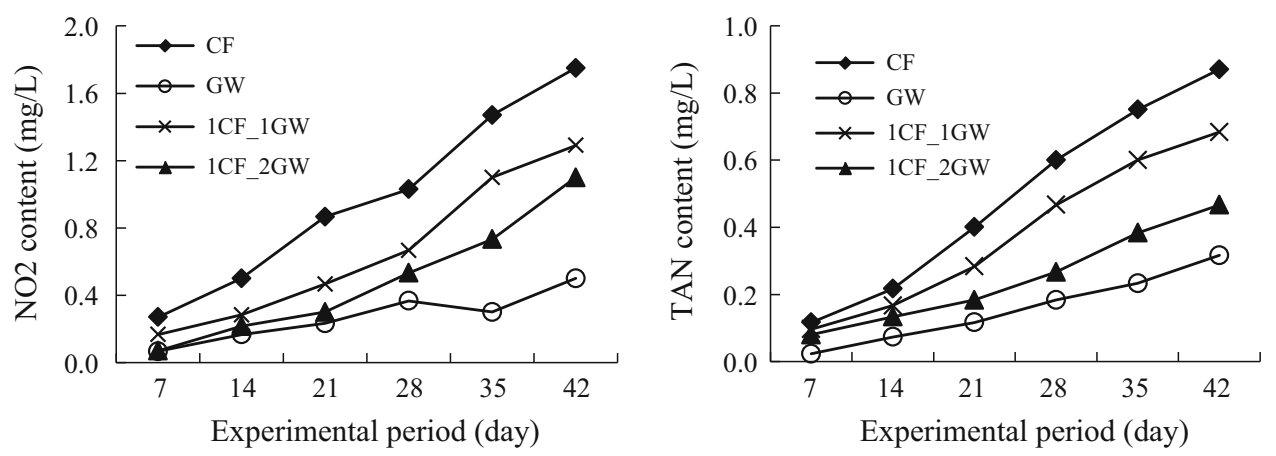

Fig. 1 Variation in the mean concentrations of $\mathrm{NO} 2$ and TAN during experimental period 


\section{Survival rate}

The survival rates of the experimental fishes were not significantly different among treatments, varying in the ranges of 88.3-93.3, 82.7-85.3, and 93.3-100\% for Spotted scat, Red tilapia, and Giant gourami, respectively (Table 1). Similar findings have been reported where utilization of seaweeds as fish feed did not affect survival rate of experimental fishes (Swain and Padhi 2011; Guroy et al. 2011).

\section{Growth performance}

There was high variability in the final weight and SGR of experimental fish in the different treatments (Table 1).

For the Spotted scat, alternate feeding 1CF_1GW and 1CF-2GW resulted in significantly higher growth compared to the control (commercial feed) and the group fed solely GW. However, fish fed on only GW had similar growth to the control group. This could be related to fish feeding habit of the species. Gandhi (2002) studied on the food and feeding habits of Spotted scat, and indicated that GW dominated the gut contents in fishes of size above 50-100 $\mathrm{mm}$ in total length. On the other hand, better water quality in the group received solely GW may also support the fish growth (Siddik et al. 2014a). For Red tilapia, growth of fish receiving alternate feeding regimes of $\mathrm{CF}$ and $\mathrm{GW}\left(1 \mathrm{CF} \_1 \mathrm{GW}\right.$ and $\left.1 \mathrm{CF} \_2 \mathrm{GW}\right)$ was also comparable to the control group, while the lowest growth rates were observed in the group fed single GW which was significantly different from other treatments.

Growth performances of Giant gourami followed similar pattern as observed for the red tilapia. Growth rate of the fish fed 1CF_1GW was equivalent to those receiving solely CF. When fish received 1CF_2GW, their growth was significantly lower than the control and the $1 \mathrm{CF}_{-} 1 \mathrm{GW}$ treatments. Fish fed only on GW showed the lowest growth compared to other treatments. In Vietnam, herbivorous fish are preferred in household-scale

Table 1 Growth, survival rate, and food conversion ratio (dry weight) of three herbivorous fishes in four different feeding regimes (mean values \pm SD)

\begin{tabular}{|c|c|c|c|c|c|c|}
\hline \multirow[t]{2}{*}{ Parameters } & \multirow[t]{2}{*}{ Final weight $(g)$} & \multirow[t]{2}{*}{$\operatorname{SGR}\left(\%\right.$ day $\left.^{-1}\right)$} & \multirow[t]{2}{*}{ Survival (\%) } & \multicolumn{2}{|l|}{ FCR } & \multirow[t]{2}{*}{$\mathrm{CF}$ reduced to control $(\%)$} \\
\hline & & & & $\begin{array}{l}\text { Commercial } \\
\text { feed }\end{array}$ & Gut weed & \\
\hline \multicolumn{7}{|c|}{ Spotted scat (S. argus) reared for 60 days } \\
\hline $\begin{array}{l}\mathrm{CF} \\
\quad(\text { control })\end{array}$ & $9.66 \pm 2.27^{\mathrm{c}}$ & $2.66 \pm 0.42^{\mathrm{b}}$ & $93.3 \pm 6.7$ & $2.07 \pm 0.17$ & - & - \\
\hline $1 \mathrm{CF}-1 \mathrm{GW}$ & $8.13 \pm 2.06^{\mathrm{a}}$ & $2.36 \pm 0.46^{\mathrm{a}}$ & $86.7 \pm 3.3$ & $1.53 \pm 0.04$ & $0.97 \pm 0.06$ & -26.1 \\
\hline $1 \mathrm{CF}-2 \mathrm{GW}$ & $8.26 \pm 1.89^{\mathrm{ab}}$ & $2.40 \pm 0.38^{\mathrm{a}}$ & $88.9 \pm 1.9$ & $1.18 \pm 0.14$ & $1.46 \pm 0.04$ & -43.0 \\
\hline GW & $9.03 \pm 1.35^{\mathrm{bc}}$ & $2.58 \pm 0.26^{\mathrm{b}}$ & $88.3 \pm 7.1$ & - & $2.82 \pm 0.03$ & -100 \\
\hline \multicolumn{7}{|c|}{ Red tilapia (O. niloticus) reared for 45 days } \\
\hline $\begin{array}{l}\mathrm{CF} \\
\quad \text { (control) }\end{array}$ & $10.76 \pm 2.33^{\mathrm{b}}$ & $2.31 \pm 0.51 b$ & $84.0 \pm 0.0$ & $1.56 \pm 0.12$ & - & - \\
\hline 1CF-1GW & $10.63 \pm 2.59^{\mathrm{b}}$ & $2.28 \pm 0.51^{\mathrm{b}}$ & $82.7 \pm 2.3$ & $1.05 \pm 0.17$ & $0.27 \pm 0.28$ & -32.7 \\
\hline $1 \mathrm{CF}-2 \mathrm{GW}$ & $10.25 \pm 2.13^{\mathrm{b}}$ & $2.20 \pm 0.48^{\mathrm{b}}$ & $85.3 \pm 2.3$ & $0.87 \pm 0.09$ & $0.41 \pm 0.05$ & -44.2 \\
\hline GW & $7.10 \pm 1.29^{\mathrm{a}}$ & $1.40 \pm 0.40^{\mathrm{a}}$ & $84.0 \pm 4.0$ & - & $2.47 \pm 0.35$ & -100 \\
\hline \multicolumn{7}{|c|}{ Giant gourami (O. goramy) reared for 56 days } \\
\hline $\begin{array}{l}\mathrm{CF} \\
\quad \text { (control) }\end{array}$ & $6.10 \pm 0.88^{\mathrm{c}}$ & $1.74 \pm 0.26^{\mathrm{c}}$ & $98.3 \pm 2.9$ & $1.99 \pm 0.27$ & - & - \\
\hline $1 \mathrm{CF}-1 \mathrm{GW}$ & $5.97 \pm 0.83^{\mathrm{c}}$ & $1.71 \pm 0.26^{\mathrm{c}}$ & $100 \pm 0.0$ & $1.03 \pm 0.07$ & $0.95 \pm 0.06$ & -48.2 \\
\hline $1 \mathrm{CF}-2 \mathrm{GW}$ & $5.28 \pm 0.86^{\mathrm{b}}$ & $1.48 \pm 0.28^{\mathrm{b}}$ & $93.3 \pm 2.9$ & $0.84 \pm 0.06$ & $1.41 \pm 0.04$ & -57.8 \\
\hline GW & $4.60 \pm 0.70^{\mathrm{a}}$ & $1.24 \pm 0.27^{\mathrm{a}}$ & $95.0 \pm 5.0$ & - & $3.29 \pm 0.12$ & -100 \\
\hline
\end{tabular}

Values are mean \pm standard deviation. Mean values in each column bearing different superscripts are significantly different $(P<0.05)$. Average initial weights of experimental fishes were $1.90 \pm 0.19,3.72 \pm 0.34$, and $2.27 \pm 0.22 \mathrm{~g}$ for the Spotted scat, Red tilapia, and Giant gourami, respectively

$C F$ commercial feed, $F G W$ fresh gut weed, $D G W$ dried gut weed 
culture systems that primarily produce fish for home or local consumption (Anh et al. 2012; Siddik et al. 2014a). In particular Spotted scat, Red tilapia, Giant gourami, and other species are fed on aquatic plants, macroalgae, and grass, which are abundant in the Mekong delta. However, a combination of natural food (macroalgae, aquatic plants) with pellet feed can reduce the production cycle (Ergun et al. 2009; Guroy et al. 2013).

\section{Feed conversion ratio}

Since fresh GW is not available all the year round, dried GW was obtained by air drying of biomass till reaching a moisture content of $12-14 \%$ for using as fish diet. In the present study, the highest FCR was observed in the fish fed on single CF in three fish species. With respect to the use of GW as single feed, FCRs of GW were much higher (2.47-3.29) than using solely CF (1.56-2.07). This could be due to different proximate composition between $\mathrm{CF}$ and $\mathrm{GW}$ as $\mathrm{CF}$ contains $\geq 30 \%$ crude protein and $\geq 6 \%$ lipid, while GW had average crude protein and lipid of 12.7 and $2.4 \%$, respectively. However, when combined feeding of CF and fresh or dried GW were applied, the FCR of CF was considerably reduced in all species. The reduction was from 26.1 to $43.0 \%$ in Spotted scat, from 32.7 to $44.2 \%$ in Red tilapia, and from 48.2 to $57.8 \%$ in Giant gourami, respectively. This approach could help farmers reduce the feed cost and enhance profit.

\section{Conclusions}

The findings of this study confirmed that GW may be combined with CF in order to reduce the feed costs and improve the water quality in the culture system. This result also may encourage feed manufacturers and fish farmers generating low-cost aquafeed production.

Acknowledgments This study was funded by the Belgian Government (VLIR-UOS) scholarship. The authors would like to express their sincere thanks to College of Aquaculture and Fisheries, Can Tho University (CTU), Vietnam for their logistics and manpower support.

Conflict of interest The authors declare that they have no competing interests.

Authors' contributions MABS was responsible for conducting experiments, analysis of data, and wrote the manuscript. NTNA developed the initial idea, designed the study, and finalized the manuscript. Both authors read and approved the final manuscript.

Open Access This article is distributed under the terms of the Creative Commons Attribution License which permits any use, distribution, and reproduction in any medium, provided the original author(s) and the source are credited.

\section{References}

Aguilera-Morales M, Casas-Valdez M, Carrillo-Dominguez S, Gonzalez-Acosta B, Perez-Gil F (2005) Chemical composition and microbiological assays of marine algae Enteromorpha spp. as a potential food source. J Food Compos Anal 18:79-88

Ahsan ME, Wahab MA, Siddik MAB, Alam MA, Sharker MR, Nahar A (2013) Impacts of inclusion of column feeder rohu (Labeo rohita) at different stocking densities on growth, production and environment in freshwater prawn-carp-mola polyculture system. Int J Biol Res 1(2):48-54

Anh NTN, Tien NM, Hai TN (2012) Proceedings of the 12th International Fisheries on sharing knowledge for sustainable aquaculture and fisheries in the South-East Asia, Can Tho University, Vietnam, 6-8th December 2012

AOAC (2005) Official methods of analysis of chemist, 18th edn. AOAC International, Maryland

Boyd CE (2003) Guidelines for aquaculture effluent management at the farm-level. Aquaculture 226:101-112

El-Sayed AFM (1999) Alternative dietary protein sources for farmed tilapia, Oreochromis spp. Aquaculture 179:149-168

Ergun S, Soyuturk M, Guroy B, Guroy D, Merrifield D (2009) Influence of Ulva meal on growth, feed utilization, and body composition of juvenile Nile tilapia (Oreochromis niloticus) at two levels of dietary lipid. Aquacult Int 17:355-361

FAO (2011) Demand and supply of feed ingredients for farmed fish and crustaceans. FAO Fisheries and Aquaculture Technical paper No. 564, ISBN 2070-7010, Rome, Italy

Gandhi V (2002) Studies on the food and feeding habits of cultivable butterfish Scatophagus argus). J Mar Biol Ass India 44:115-121

Guroy D, Guroy B, Merrifield DL, Ergun S, Tekinay AA, Yigit M (2011) Effect of dietary Ulva and Spirulina on weight loss and body composition of rainbow trout, Oncorhynchus mykiss (Walbaum), during a starvation period. J Anim Physiol Anim Nutr 95:320-327 
Guroy B, Ergun S, Daniel LM, Guroy D (2013) Effect of autoclaved Ulva meal on growth performance, nutrient utilization and fatty acid profile of rainbow trout, Oncorhynchus mykiss. Aquacult Int 21:605-615

Haroon AM, Szaniawska A, Normant M, Janas U (2000) The biochemical composition of Enteromorpha spp. from the Gulf of Gdansk coast on the Southern Baltic Sea. Oceanologia 42:19-28

Kaushik SJ, Covès D, Dutto G, Blanc D (2004) Almost total replacement of fish meal by plant protein sources in the diet of a marine teleost, the European seabass, Dicentrarchus labrax. Aquaculture 230:391-404

Pereira R, Valente LMP, Sousa-Pinto I, Rema P (2012) Apparent nutrient digestibility of seaweeds by rainbow trout (Oncorhynchus mykiss) and Nile tilapia (Oreochromis niloticus). Algal Res 1:77-82

Rad A, Zakeri MM, Yavari V, Mosavi SM (2013) Effect of different levels of dietary supplementation of Saccharomyces cerevisiae on growth performance, feed utilization and body biochemical composition of Nile Tilapia (Oreochromis niloticus) fingerlings. World J Fish Mar Sci 5(1):88-95

Rahman MM, Jo Q, Gong YG, Miller SA, Hossain MY (2008) A comparative study of common carp (Cyprinus carpio L.) and calbasu (Labeo calbasu Hamilton) on bottom soil resuspension, water quality, nutrient accumulations, food intake and growth of fish in simulated rohu (Labeo rohita Hamilton) ponds. Aquaculture 285:78-83

Shanmugan A, Palpandi C (2010) Biochemical composition and fatty acid profile of the green alga Ulva reticulata. Asian J Biochem 5(3):188-193

Siddik MAB, Nahar A, Rahman NM, Anh NTN, Nevejan N, Bossier P (2014a) Gut Weed, Enteromorpha sp. as a partial replacement for commercial feed in Nile Tilapia (Oreochromis niloticus) culture. World J Fish Mar Sci 6(3):267-274

Siddik MAB, Nahar A, Ahamed F, Hossain MY (2014b) Over-wintering growth performance of mixed-sex and mono-sex Nile tilapia Oreochromis niloticus in northeastern Bangladesh. Croat J Fish 72:70-76

Swain PK, Padhi SB (2011) Utilization of seaweeds as fish feed in aquaculture. J Biol Sci Biohelica 2:35-46

Valente LMP, Gouveia A, Rema P, Matos J, Gomes EF, Pinto IS (2006) Evaluation of three seaweeds Gracilaria bursa, Ulva rigida and Gracilaria cornea as dietary ingredients in European sea bass (Dicentrarchus labrax) juvenile. Aquaculture 252:85-91

Zhao Z, Xu Q, Luo L, Wang C, Li J, Wang L (2014) Effect of feed C/N ratio promoted bioflocs on water quality and production performance of bottom and filter feeder carp in minimum-water exchanged pond polyculture system. Aquaculture 434:442-448 